\title{
An Error Analysis of the Use of Prepositions in Students' Descriptive Writing
}

\author{
Riska Nurhamidah* \\ State Islamic University of North Sumatera \\ Medan, Indonesia \\ https:// orcid.org/0000-0001-9624-4509

\begin{tabular}{|c|c|c|}
\hline Received & Revised & Accepted \\
\hline 25 August 2021 & 29 October 2021 & 15 November 2021 \\
\hline
\end{tabular}

\begin{abstract}
This research aims to identify the types of students' errors in using prepositional place in the descriptive text made by eighth grade (8) students to identify the cause of errors made by students in using prepositional place. That most of the students did not pay attention to use prepositional correctly in a sentence. This research is qualitative research. The research object shows four types of the error made by students, omission, addition, misordering, and misformation. Based on the data, the frequency of students' error in using prepositional place mainly occurred in prepositional in place in 35 errors. The second is prepositional on with 14 errors. The third is the prepositional place at with 12 errors.
\end{abstract}

Keywords: Error Analysis, Prepositional Place, Descriptive Text

\section{Introduction}

"State that Language is a very important in human life for communication within each other that makes it easy to get along. With language, we are able to express our feelings, our thoughts, and our experiences with others." (Zubaidah, 2015, p.21).

It means that language is a means of human effort to carry out their activities. Although human beings process of speaking language, unfortunately, it has not been straightforward for them to say what it is. "Writing is one of the main skills that play an important role." (Harmer, 2000, p.16).

"Writing is one of the main skills that play an important role. Writing is a language skill that language produces and is therefore often referred to as skill. Writing is one of the skills that is considered to have an essential significance in the second language (L2) learning because it serves as both a tool for communication and a means of learning, thinking, and organizing knowledge or ideas." (Fithriani, 2008).

Based on the previous explanation, it can be concluded that writing is critical because students can express their ideas, thought, and arguments through a sentence. However, many students have difficulty writing. Therefore, students in writing make some mistakes. It is because of students' inaccuracies in their writing and also because of students' inability. Error conducted by students mainly about prepositions.

* Corresponding author: Riska Nurhamidah, riskaanurhamidah@gmail.com 
Students who learn a foreign language will undoubtedly find difficulty, such as they learn English. Grammar is an essential aspect of learning language because grammar will help learners write words and sentences correctly.

"Grammar is the natural inherent meaning-making system of the language, a system that governs the way words come together to form meaning, grammar is also the study of that system, the various theories or perspectives that attempt to understand and describe it." Craig Hancock $(2005 ; 6)$

In English lessons, especially about writing and understanding words and sentences, students do not really understand it. Based on the observation in MTS Swasta ALJumhuriyah North Sumatera, the researcher found placement errors of a preposition when the students do exercises on prepositions material.

\section{Literature Review}

Error is one of the things that occur in the language learning process. As well as in learning English, most students will make an error. For example, "When the children learn mother tongue, sometimes the use improper pronouns, ambiguous words or incorrect word formation." (Rido, 2000).

"Error analysis is a technique for identifying, classifying, and systematically interpreting the unacceptable forms produced by someone learning a foreign language, using any of the principles and procedures provided by linguistics." (Brown, 2007)

Error analysis can be a useful device for a foreign language teaching program. Errors provide feedback, and they tell the lecturers something about their teaching materials' effectiveness and teaching techniques.

Dulay in Kuntjara (2013) divided error into five types; they are Omission, Addition, Misformation, Mis-ordering, and Blends.

a. Omission

Omission is any deletion of certain necessary items in sentences. Omission is indicated by the absence of a specific item that must appear in the sentence. This usually happens in the early stages of second language acquisition. For example: "My mother smart cooking." It should be, "my mother is smart in cooking."

b. Addition

Addition is any usage of unnecessary items in the sentences. The addition is indicated by the presence of an 'unwanted' item in sentences. The unwanted items do not appear in a well-formed utterance. This happens when the learners overuse specific grammatical rules of the target language. For example: "He does not to come." It should be "He does not come."

c. Mis-formation

Misinformation errors are characterized by the use of the wrong form of the morpheme. It means that one or more sentence aspect has the wrong formation. It can be caused by rule regularization. For example: "She have a tall body." It should be "She has a tall body."

d. Mis-ordering

Mis-ordering is any incorrect placement of certain morphemes in a sentence. For example: "she fights all the time her brother." It should be "she fights her brother all the time." 


\section{e. Auxiliary Verb Forms}

The use of simple present tense often makes students confused with its complexity. They usually have some problems in finding out the verb form of simple present tense. For example: "He walk to school every day." It should be "He walks to school every day."

In conducting an error analysis, there are some procedures as Corder (2008; 46-60) distinguishes into five steps:

a. Collection a sample of learner language

b. Identification of errors

c. Description of errors

d. Explanation of errors

e. Error evaluation

The first step is collecting a sample of learner language. Then, it provides the data obtained by giving and collecting a test containing prepositions of time and place to students. The second step is the identification of errors - the process of identifying students'errors based on the tested area. The third step is a description of errors. It involves describing or specifying how errors form produced by students. Finally, the fourth is an explanation of errors.

This step attempts to explain there as one of the students'" errors happened. It involves determining their sources in order to account for why they were made. From the point of view of second language acquisition research, this is the most crucial stage in error analysis. The last step is error evaluation, evaluating the errors made by students. Error evaluation is the analysis of learner errors as supplementary produce for applying the results of error analysis. It involves determining the gravity of different errors to decide which ones should receive instruction.

"Writing descriptive text is a process of writing text that describes people, place, object, or thing. Descriptive is a text which says what a person's thing is like. Its purpose of describing and revealing a particular person, place, or thing." (Boardman \& Frydenberg, 2008;19)

"Descriptive text creates a clear and vivid impression of person, place, or thing. More often, Descriptive text is a part of factual genres." (Wiener, 2001, p.25)

"States that its social function is to describe a particular person, place or thing." (Wardman et el, 2008, p.122)

Writing is considered one of the problematic abilities for most students. That is why students must produce a sentence or text using English correctly and in accordance with the order of tenses grammatically. "Writing was the process of transferring the language through letters, symbol, or words." (Dewi, 2013, p.2)

This research will analyse qualitative research. First, the researcher will focus on one variable. The variable focuses on types of student errors in using the preposition in, on, at. The indicators are operationally conceptualized as follows: omission of a preposition in, on, at; insertion of a preposition in, on, at; selection of incorrect of a preposition in, on, at; preposition in, on, at to showplace. After identifying the students' writing errors, the researcher categorizes them in their type to find the dominant error, which the students do. 


\section{Methodology}

This research was conducted at MTS Swasta Al-Jumhuriyah North Sumatra. The subjects of this research were the students in the eighth grade of MTS Al-Jumhuriyah North Sumatera.

\subsection{Research Design}

In this research, the writer uses descriptive qualitative research. The descriptive method is the appropriate way to find the errors made by students in using prepositional places in writing descriptive text. The purpose of qualitative is to help the writer find the solution to the phenomenon that they studied. The writer analyses students writing tests in descriptive text. The result of the test will use as the primary data of this research. The writer gives the questioners to know the causes of the errors made by the students.

The test was set as the data collection tool. When the data were collected, they were being classified based on its errors source. From those data, the writer will do an analysis, and there will be data analysis to conclude.

\subsection{Subject of The Study}

The target of study, the writer selected students who study in MTS Swasta Al- Jumhuriyah as an object. Moreover, the sample of the study was VIII-2.

To collect this research data, the writer will use an interview with an English teacher and some students. The writer used document analysis as a technique in collecting the data. Before giving the test, the writer would observe the teaching-learning process in the classroom.

\subsection{Technique of Collecting Data}

The writer would take the students' last task in descriptive text using the preposition of place. Then, data was collected through a test of descriptive text by using prepositional place in, on, at. Furthermore, the last the writer gives the questionnaires as the instrument to collect the data. Arikunto $(2013 ; 193)$ stated that "test is question or exercise use to measure the knowledge and ability to understand individual or group."

Before the students do the test, the researcher would give instructions on doing the writing test. Then, the writer will explain to remind the students about rules in using prepositional place, especially in, on, at. Next, the students were given 30-40 minutes to write a descriptive text using prepositional place in, on, at. After that, the writer would collect the students' writing tests.

\subsection{Technique of Data Analysis}

According to James (1998), there are five procedures identification of errors, they are:

1) Error Detection

The data was collected to find out the errors by underlining the errors.

2) Locating Error

The error determines when students omitted necessary items or added necessary ones, omission, addition, misinformation, or misordering.

3) Describing Error 
The writer made a table to describe all the students' errors. And then, the writer made a table to describe errors in omission, errors, in addition, errors in misinformation, and errors in misordering.

4) Classifying Error

The writer classified errors into the table to draw up the result of each error to present the total of each error and the total of all errors.

5) Counting Error

After classifying the data, the writer calculates the percentage of each error type. Then, to do the last step, which is quantifying each percentage of error. The formula was used.

$\mathrm{P}=\mathrm{F} / \mathrm{N} \times 100 \%$

Note:

$\mathrm{P}=$ percentage of error

$\mathrm{F}=$ frequency of errors occurred

$\mathrm{N}=$ number of cases (total frequent/ total individual)

\section{Results and Discussion}

To explain the researcher's observations by making direct observations of the learning activities carried out by class VIII-2 students at MTs Al-Jumhuriyah North Sumatera. Furthermore, the researcher conducted interviews with several sources directly related to this study by conducting direct and in-depth questions and answers, namely the English teacher and some students (interview list attached). In the result observation, the researcher found that the students of VIII-2 felt confused to understand using prepositional place because they did not know the meaning of the words.

Moreover, the result of interviews with students of VIII-2 is that they were not confident answering a question or finishing their assignment because they thought English was complicated and did not know the meaning. For example, one of them said they did not know the sentence's meaning, so they were confused about the used prepositional place in the sentence. The result of the test is as follow:

Table 1: The Score Test Result

\begin{tabular}{cccccc}
\hline No & Sample & Score & No & Sample & Score \\
\hline 1 & AP & 37.5 & 9 & NM & 75 \\
\hline 2 & CSR & 50 & 10 & NS & 50 \\
\hline 3 & FA & 50 & 11 & RD & 87.5 \\
\hline 4 & FM & 50 & 12 & RM & 62.5 \\
\hline 5 & G & 50 & 13 & S & 37.5 \\
\hline 6 & MA & 50 & 14 & TS & 62.5 \\
\hline 7 & MH & 37.5 & 15 & W & 62.5 \\
\hline 8 & MR & 50 & 16 & ZW & 25 \\
\hline \multicolumn{5}{c}{ Average Score } \\
\hline \multicolumn{7}{c}{ Highest Score } \\
\hline
\end{tabular}


Based on Table 1, the researcher found the students' scores of test results about the prepositional place. The average score was 52,3 . The highest score was 87,5 (RD), while the lowest score was $25(\mathrm{ZW})$.

From the data collected, the researcher breaks down the students' error occurrence based on the three areas: prepositional place In, On, At.

Table 2: The Identification of Students' Error in Using Prepositional Place In

\begin{tabular}{|c|c|c|c|}
\hline Original Sentence/Phrase & Type of Error & Cause of Error & Correction \\
\hline $\begin{array}{l}\text { Maimun Palace is a tourist } \\
\text { destination in North } \\
\text { Sumatera }\end{array}$ & Mis-formation & $\begin{array}{l}\text { Ignorance of Rule } \\
\text { Restrictions }\end{array}$ & $\begin{array}{l}\text { Maimun Palace is a tourist } \\
\text { destination in North } \\
\text { Sumatera }\end{array}$ \\
\hline $\begin{array}{l}\text { Maimun Palace is a tourist } \\
\text { destination on North } \\
\text { Sumatera }\end{array}$ & Mis-formation & $\begin{array}{l}\text { Ignorance } \\
\text { of Rule } \\
\text { Restrictions }\end{array}$ & $\begin{array}{l}\text { Maimun Palace is a tourist } \\
\text { destination in North } \\
\text { Sumatera }\end{array}$ \\
\hline $\begin{array}{l}\text { It was designed by an } \\
\text { Italian architect and built- } \\
\text { in } 1888 \text { under the Rule of } \\
\text { Sultan Makmun Al Rasyid } \\
\text { Perkasa, the Sultan of } \\
\text { Deli. }\end{array}$ & Mis-formation & $\begin{array}{l}\text { Overgeneralizatio } \\
\mathrm{n}\end{array}$ & $\begin{array}{l}\text { It was designed by an Italian } \\
\text { architect and built-in } 1888 \\
\text { under the Rule of Sultan } \\
\text { Makmun Al Rasyid Perkasa, } \\
\text { the Sultan of Deli. }\end{array}$ \\
\hline $\begin{array}{l}\text { It was designed by an } \\
\text { Italian architect and built- } \\
\text { in } 1888 \text { under the Rule of } \\
\text { Sultan Makmun Al Rasyid } \\
\text { Perkasa, the Sultan of } \\
\text { Deli. }\end{array}$ & Mis-formation & $\begin{array}{l}\text { Ignorance of Rule } \\
\text { Restrictions }\end{array}$ & $\begin{array}{l}\text { It was designed by an Italian } \\
\text { architect and built-in } 1888 \\
\text { under the Rule of Sultan } \\
\text { Makmun Al Rasyid Perkasa, } \\
\text { the Sultan of Deli. }\end{array}$ \\
\hline $\begin{array}{l}\text { Seven of which are at the } \\
\text { main building, }\end{array}$ & Mis-formation & $\begin{array}{l}\text { Overgeneralizatio } \\
\mathrm{n}\end{array}$ & $\begin{array}{l}\text { Seven of which are in the } \\
\text { main building, }\end{array}$ \\
\hline $\begin{array}{l}\text { Seven of which are on the } \\
\text { main building, }\end{array}$ & Mis-formation & $\begin{array}{l}\text { Ignorance of } \\
\text { Rule }\end{array}$ & $\begin{array}{l}\text { Seven of which are in the } \\
\text { main building, }\end{array}$ \\
\hline $\begin{array}{l}\text { Three rooms on the left- } \\
\text { wing part }\end{array}$ & Mis-formation & $\begin{array}{l}\text { Ignorance of Rule } \\
\text { Restrictions }\end{array}$ & $\begin{array}{l}\text { Three rooms in the left-wing } \\
\text { part }\end{array}$ \\
\hline $\begin{array}{l}\text { Three rooms at the left- } \\
\text { wing part }\end{array}$ & & $\begin{array}{l}\text { Overgeneralizatio } \\
\mathrm{n}\end{array}$ & $\begin{array}{l}\text { Three rooms in the left-wing } \\
\text { part }\end{array}$ \\
\hline $\begin{array}{l}\text { Three other rooms on the } \\
\text { right-wing part }\end{array}$ & Mis-formation & $\begin{array}{l}\text { Ignorance of Rule } \\
\text { Restrictions }\end{array}$ & $\begin{array}{l}\text { Three other rooms in the } \\
\text { right-wing part }\end{array}$ \\
\hline $\begin{array}{l}\text { Three other rooms at the } \\
\text { right-wing part }\end{array}$ & Mis-formation & $\begin{array}{l}\text { Overgeneralizatio } \\
\mathrm{n}\end{array}$ & $\begin{array}{l}\text { Three other rooms in the } \\
\text { right-wing part }\end{array}$ \\
\hline
\end{tabular}

Based on Table 2, 6 students made errors in item number 1,8 students who made errors in item number 4, 10 students who made errors in item number 6, 6 students who made errors in item number 7, 5 students who made errors in item number 8 . Therefore, it could be stated that most students' errors in using prepositional place In occurred in number. 
Table 3: The Identification of Student's Error in Using Prepositional Place on

\begin{tabular}{|c|c|c|c|}
\hline Original Sentence/Phrase & Type of Error & Cause of Error & Correction \\
\hline $\begin{array}{l}\text { The building stands at an } \\
\text { area of } 2,772 \text { square meters } \\
\text { and is the heritage of the } \\
\text { Deli Sultanate. }\end{array}$ & Mis-formation & $\begin{array}{l}\text { Ignorance of Rule } \\
\text { Restrictions }\end{array}$ & $\begin{array}{l}\text { The building stands on an } \\
\text { area of } 2,772 \text { square } \\
\text { meters and is the heritage } \\
\text { of the Deli Sultanate. }\end{array}$ \\
\hline $\begin{array}{l}\text { The building stands In an } \\
\text { area of } 2,772 \text { square meters } \\
\text { and is the heritage of the } \\
\text { Deli Sultanate. }\end{array}$ & Mis-formation & $\begin{array}{l}\text { Ignorance of } \\
\text { Rule } \\
\text { Restrictions }\end{array}$ & $\begin{array}{l}\text { The building stands on an } \\
\text { area of } 2,772 \text { square } \\
\text { meters and is the heritage } \\
\text { of the Deli Sultanate. }\end{array}$ \\
\hline $\begin{array}{l}\text { There are } 13 \text { rooms in the } \\
\text { second floor, }\end{array}$ & Mis-formation & $\begin{array}{l}\text { Ignorance of } \\
\text { Rule } \\
\text { Restrictions }\end{array}$ & $\begin{array}{l}\text { There are } 13 \text { rooms on the } \\
\text { second floor, }\end{array}$ \\
\hline $\begin{array}{l}\text { There are } 13 \text { rooms at the } \\
\text { second floor, }\end{array}$ & Mis-formation & $\begin{array}{l}\text { Ignorance of } \\
\text { Rule } \\
\text { Restrictions }\end{array}$ & $\begin{array}{l}\text { There are } 13 \text { rooms on the } \\
\text { second floor, }\end{array}$ \\
\hline
\end{tabular}

Based on Table 3, 12 students made errors in item number 3, 2 students made errors in item number 5. Therefore, it could be stated that most of the students' errors in using prepositional place on occurred in number 12.

Table 4: The Identification of Student's Error in Using Prepositional Place At

\begin{tabular}{llll}
\hline \multicolumn{1}{c}{ Original Sentence/Phrase } & Type of Error & Cause of Error & \multicolumn{1}{c}{ Correction } \\
\hline Located on Jalan Brigjen & Mis-formation & Ignorance of Rule & Located at Jalan Brigjen \\
Katamso, Aur, Medan, this & & Restrictions & Katamso, Aur, Medan, \\
palace is iconic to Medan. & & & $\begin{array}{l}\text { this palace is iconic to } \\
\text { Medan. }\end{array}$ \\
\hline
\end{tabular}

Based on Table 4, 12 students made errors using prepositional at. The researcher intends to explain the error by finding out the sources of error. Two primary sources of error are considered: overgeneralization and ignorance of rule restrictions.

Overgeneralization is one of the common causes of error in this research. It generally happens when the students apply the previous Rule that they have learned before to another pattern with a different rule. For examples:

- Julia was born on 1998.

- I usually study English in the night.

- There is a Post Office at Sudirman Street.

The sentences above show that the students make generalizations in using prepositions. 
For example, the student applies the preposition of time on in a sentence," Julia was born on 1998," due to the material being learned previously. The students assume that the use of the preposition of time on, in this case, is the same as the rule of day or date of the month. It is incorrect.

The researcher uses the types of errors based on surface strategy taxonomy to classify the students" errors in using prepositions of time and place. The table is described as follows:

Table 5: The Classification of Students' Error

\begin{tabular}{clc}
\hline No. & Error Classification & Frequency of Errors \\
\hline 1 & Omission & - \\
\hline 2 & Addition & - \\
\hline 3 & Mis-formation & 61 \\
\hline 4 & Mis-ordering & - \\
\hline & Total & 61
\end{tabular}

The table above shows that the students' error is totally mis-formation. It is 61 errors found of 16 students in using prepositional place. There is no error committed by students in omission, addition, and misordering.

\section{Conclusion}

Based on the collecting data and discussion in the previous chapter, the researcher has analyzed the students' errors in using prepositional place. The collecting data shows that the VIII-2 students of MTS Swata Al-Jumhuriyah North Sumatera still make some errors in using prepositional places in descriptive text.

Based on the data, the frequency of students" errors in using prepositional places mainly occurred in prepositional places in 35 errors. The second is prepositional on with 14 errors. The third is prepositional place on with 12 errors.

The types of errors that the students made are misordering, omission, addition, and misformation. From the classification of student errors, it is totally mis-formation with 61 errors. Students commit no error in omission, addition, or misordering.

Based on the occurrence of the errors, most of the errors are caused by ignorance of rule restrictions which is influenced by the students" fail to apply the rules to where they do not apply. Meanwhile, Overgeneralization generally happens when the students apply the previous rule they learned before to another pattern with a different rule.

The solution for the students' using prepositional place is that the English teacher should try to overcome the students' problem by giving more explanations and exercises. Moreover, giving the material as straightforward as possible and giving the students more detail about the prepositional place, their function, differences, and different rules between a prepositional place in English and Indonesia.

The English teachers should give more attention to deliver the materials of the preposition of time and place. They should choose the best method and present the materials clearly so that students understand materials easily. In the teaching-learning process, the students must be active and ask something about using prepositional place. The researcher hopes 
the students increase their effort in learning grammar, and they have to be accustomed to learning English writing skills when they are in the classroom or their house.

\section{References}

Boardman, C. A., \& Frydenberg, J. (2008). Writing to communicate 2: Paragraphs and essays. Pearson/Longman.

Brown, H. Douglas. Principles of Language Learning and Teaching. Korea Selatan, Pearson Longman, 2007.

Fithriani, R. (2018). Cultural influences on students' perceptions of written feedback in L2 writing. Journal of Foreign Language Teaching and Learning, 3(1), 1-13.

Hancock, Craig. (2005). Meaning-Centered Grammar. London: Equinox

Harmer, J. (2007). The Practice of English Language Teaching, Harlow: Longman

Harvey S. Wiener. (2001). Creating Competition. Singapore: Mc Graw-Hill

James, C. (1998). Errors in language learning and use. Exploring error analysis. Longman, London - New York.

Kuntjara, E. (2013). Creating Identities through Facebook Online Comments: A postmodernist perspective on Indonesian Youth Culture. Merit Research Journal, 1(5), 059-066.

Rido, V. (2000). Types Of Correction Supporting The Leaner-Centered Learning in English Classes. New York: Addison Wesley Longman

Suharsimi, Arikunto. (2013). Prosedur Penelitian: Suatu Pendekatan Praktik. Jakarta : Rineke Cipta

Utami, D. (2013). How to Write. Medan : La-Tansa Press

Wardiman, A., Jahur, M. B., \& Djusma, M. S. (2008). English in focus for grade VIII junior high school (SMP/MTs). Jakarta: Pusat perbukuan departemen pendidikan nasional.

Zubaidah, S. (2015). Contrastive and Error Analysis, Medan : CV.Gemilang Utama 